\title{
Table of EU Treaties and Agreements
}

Agreement on a Unified Patent Court [2013] OJ C175/1 .................................. 142

Multilateral Agreements resulting from the trade negotiations of 1973-1979

(GATT) - Agreement on government procurement - Notes [1980] OJ L71/

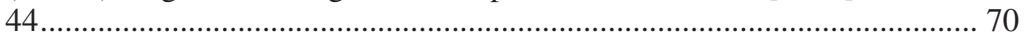

Treaty Establishing the European Community (Consolidated Text) [2002] OJ

C325/33 (Articles 113, 295) ............................................................... 171

Treaty Establishing the European Stability Mechanism [2011] OJ L91/1 ............ 24

Treaty of Lisbon Amending the Treaty on European Union and the Treaty

Establishing the European Community [2007] OJ C306/1

Treaty on European Union (Consolidated Text) [2012] OJ C326/13 (Article 20)

Treaty on Stability, Coordination and Governance [2012] $20,25,172$

Treaty on the Functioning of the European Union (Consolidated Text) [2012] OJ

C326/47 (Articles 6, 8-13, 17, 45, 101, 121, 207, 326-334, 345) ... 152, 28, 98, 